Terakreditasi: SK No.: 60/E/KPT/2016

Website : http://ejournal.undip.ac.id/index.php/reaktor/

Reaktor, Vol. 16 No. 4, Desember Tahun 2016, Hal. 161-171

\title{
Optimasi Produksi Pulp Formacell dari Tandan Kosong Kelapa Sawit (TKKS) dengan Metode Permukaan Respon
}

\author{
Sri Hidayati*), Sapta Zuidar, dan Ahmad Fahreza \\ Jurusan Teknologi Hasil Pertanian Universitas Lampung \\ Jl. Sumantri Brojonegoro No. 1 Bandar Lampung \\ ${ }^{*}$ Penulis korespondensi: srihidayati.unila@gmail.com
}

\begin{abstract}
THE OPTIMATION OF FORMACELL PULP PRODUCTION FROM EMPTY FRUIT BUNCHES (EFB) USING RESPONSE SURFACE METHODOLOGY. Empty Fruit Bunches (EFB) of oil palm containing cellulose content high enough so that it can be used as an alternative raw material for pulp production. One of the pulp production process which is environmentally friendly called formacell, which used a solvent mixture of acetic acid and formic acid as a cooking ingredient. The research aimed to obtain an optimization model of the concentration of formic acid and $\mathrm{HCl}$ and duration of EFP cooking for EFB pulp production. The results showed that the optimum conditions for producing pulp is at a formic acid concentration of $32.74 \%, \mathrm{HCl}$ concentration of $0.079 \%$, and the 1.71 hours of cooking time, which produced EFB pulp with a composition of $78.37 \%$ of cellulose, $7.59 \%$ of hemicellulose, $10.71 \%$ of lignin, and a yield of $67.31 \%$.
\end{abstract}

Keywords: formacell pulp; RSM; EFB

\begin{abstract}
Abstrak
Tandan kosong kelapa sawit (TKKS) mengandung kadar selulosa yang cukup tinggi sehingga dapat dijadikan sebagai bahan baku alternatif produksi pulp. Salah satu proses produksi pulp ramah lingkungan yaitu dengan menggunakan campuran pelarut asam asetat dan asam formiat sebagai bahan pemasak yang disebut proses formacell. Penelitian ini bertujuan untuk mendapatkan model optimasi dari konsentrasi asam formiat, konsentrasi HCl dan lama pemasakan untuk produksi pulp TKKS. Konsentrasi pemasakan optimum terjadi pada konsentrasi asam formiat 32,74\%, konsentrasi $\mathrm{HCl}$ 0,079\%, dan lama pemasakan selama 1,71 jam dengan hasil optimum untuk produksi pulp TKKS yaitu 78,37\% selulosa, 7,59\% hemiselulosa, 10,71\% lignin, dan 67,31\% rendemen.
\end{abstract}

Kata kunci: pulp formacell; RSM; TKKS

How to Cite This Article: Hidayati, S., Zuidar, S., dan Fahreza, A., (2016), Optimasi Produksi Pulp Formacell dari Tandan Kosong Kelapa Sawit (TKKS) dengan Metode Permukaan Respon, Reaktor, 16(4), 161-171, http://dx.doi.org/10.14710/reaktor.16.4.161-171

\section{PENDAHULUAN}

Kayu memberikan kontribusi sampai 90\% sebagai bahan baku pulp dan kertas di dunia sehingga hal tersebut sangat berpengaruh terhadap kondisi hutan (Madakadze dkk., 1999; Aremu dkk., 2015). Residu pertanian merupakan alternatif penting untuk pengganti kayu sebagai bahan baku pada industri pulp dan kertas (Lam dkk., 2001; Jimenez dkk., 2006). Salah satu residu pertanian yang keberadaannya cukup berlimpah adalah Tandan Kosong Kelapa Sawit (TKKS). TKKS memiliki kadar selulosa 50\%, lignin $16 \%$ dan hemiselulosa 19,6\% (Law dkk., 2007), serta panjang 
serat rata-rata bagian pangkal $1,2 \mathrm{~mm}$, bilangan Runkel 0,87 , diameter serat $15 \mu \mathrm{m}$ dan tebal dinding $3,49 \mu \mathrm{m}$ (Darnoko dkk., 1995), sehingga TKKS berpotensi untuk dijadikan alternatif pembuatan pulp non kayu pengganti pulp kayu. Susanto dkk. (1999) menyatakan bahwa TKKS dapat dimanfaatkan sebagai bahan baku bagi produk-produk yang berbasis selulosa seperti pulp dan kertas. Proses pembuatan pulp dilakukan dengan cara memisahkan serat dari komponen lainnya. Proses produksi pulp masih dapat menimbulkan dampak yang kurang baik untuk lingkungan.

Salah satu proses pengolahan pulp yang ramah lingkungan adalah menggunakan pelarut organik sebagai larutan pemasak seperti asam asetat dan formiat yang dikenal sebagai proses formacell. Salah satu keuntungan menggunakan asam organik yaitu bisa digunakan sebagai pemasak sampai 10 kali siklus (Simkhovich dkk., 1987). Proses pulping menggunakan asam seperti proses secara acetosolve, formacell dan milox telah dikembangkan (Li dkk., 2012; Pan dkk., 2006; de la Torre dkk., 2013; Fang dan Sixta, 2015) yang memiliki potensi yang unggul dalam proses pemurnian dan biaya, selain itu kertas yang dihasilkan berkualitas tinggi (Aziz dan Sarkanen, 1989; Hergert, 1998; Sidiras dan Koukios, 2004). Pulping menggunakan pelarut organik untuk bahan non kayu telah dilakukan terhadap jute kulit pohon (Sahin dan Young, 2008), tongkol cardoon (Cynara cardunculus) (Ligero dkk., 2007), kulit kayu (Ligero dkk., 2005), ampas tebu (Tu dkk., 2008), dan jerami gandum (Triticum vulgare CV. Horoshiri) (Pan dan Sano, 1999) tetapi untuk penggunaan asam formiat belum banyak dilaporkan terutama pada pulp dengan bahan baku dari TKKS. Nimz dan Schoen (1993) melakukan proses formacell pada kayu, dimana lignoselulosa terdelignifikasi dengan tekanan rendah dan campuran asam asetat $(50-95 \%)$, asam formiat $(<40 \%)$, air $(<50 \%)$, dan suhu antara $130-190^{\circ} \mathrm{C}$ dengan rasio pelarut dan kayu dari 1:1 sampai 12:1 menghasilkan nilai Kappa number yang rendah dan kekuatan pulp meningkat. Proses formacell sudah diterapkan dengan bahan baku birch (Zhou dkk., 2012), bagas tebu (Zhao dan Liu, 2012), tongkol jagung (Zhang dkk., 2010).

Proses formacell memiliki banyak keunggulan yaitu menghasilkan rendemen yang tinggi, kadar lignin sisa rendah, tinggi kecerahan dan kekuatan yang baik (Aziz dan Sarkanen, 1989; Muurinen, 2000; Shatalov dan Pereira, 2004; Yawalata dan Paszner, 2004; Poujoozi dkk., 2004; Lavarack dkk., 2005; López dkk., 2006.; Rodríguez dan Jiménez, 2008). Produk sampingan yang berharga termasuk hemiselulosa dan lignin bebas sulfur fragmen. Lignin dapat digunakan untuk produksi perekat dan produk lainnya karena kemurnian tinggi, berat molekul rendah, dan reagen organik mudah direcycle.

Keberhasilan pulping menggunakan pelarut organik dipengaruhi oleh rasio pelarut dengan air, rasio antara jumlah pelarut pemasak dengan bahan yang akan dimasak, suhu pemasakan, dan lama pemasakan (Lam dkk., 2001; Ibrahim dkk., 2004; Dominggus dan
Lazslio, 2004; Goncalves dkk., 2005). Pada proses pulping memerlukan waktu yang lama dan suhu yang tinggi sehingga diperlukan katalisator untuk mempercepat proses delignifikasi. Jenis katalisator asam yang adalah $\mathrm{HCl}$ dan $\mathrm{H}_{2} \mathrm{SO}_{4}$ (Ibrahin dkk., 2004; Jahan dkk., 2006). Katalis berfungsi untuk mengurangi suhu pemasakan dan mempercepat proses pemasakan. Faktor yang berpengaruh adalah jenis katalis asam dan konsentrasi (Ligero dkk., 2005; Ibrahim dkk., 2004). Kayu tidak dapat dilakukan proses pemasakan dengan asam asetat dengan suhu di bawah $200^{\circ} \mathrm{C}$ tanpa penambahan katalis asam.

Dominggus dan Lazslio (2004) menyatakan bahwa dengan penambahan konsentrasi katalis berupa $\mathrm{HCl} 1 \%$ proses pulping dapat dilakukan pada suhu $108^{\circ} \mathrm{C}$ dengan tekanan 1 atm dibandingkan tanpa penggunaan katalis dimana suhu pulping dapat mencapai $170^{\circ} \mathrm{C}$. Penambahan konsentrasi katalis menyebabkan penghancuran polisakarida dan proses kondensasi lignin yang cepat. Hasil penelitian Goncalves dkk. (2005) menunjukkan bahwa rasio pelarut $1: 14(\mathrm{w} / \mathrm{v})$ dengan suhu pulping $110^{\circ} \mathrm{C}$, dan lama pemasakan selama 2 jam dengan katalis $\mathrm{HCl}$ memberi hasil yang baik pada pulp. Ibrahim dkk. (2004) dan Jahan dkk. (2006) menyatakan bahwa penggunaan katalis $\mathrm{H}_{2} \mathrm{SO}_{4}$ sebanyak $0,5 \%$ akan mempercepat proses delignifikasi pulp. Vila dkk. (2000) melaporkan penggunaan $\mathrm{HCl}$ pada asam asetat menghasilkan rendemen mencapai $50 \%$ dengan kadar selulosa mencapai $81,4 \%$, lignin $5,8 \%$ dan bilangan Kappa 25 sedangkan Pan dan Sano (2005) menyatakan bahwa adanya katalis $\mathrm{H}_{2} \mathrm{SO}_{4}$ mampu mengurangi xilosa pada jerami gandum sebesar $60 \%$.

Salah satu metode optimasi kondisi proses adalah Response Surface Methodology (RSM) (Rao dkk., 2002; Nogales dkk., 2005; Linder dkk., 2005). Satria dkk. (2010) melakukan optimasi pembuatan pulp semi mekanis TKKS dengan menggunakan metode RSM. Neiva dkk. (2014) melakukan optimasi pembuatan pulp Kraft dari kayu dan kulit Eucalyptus globulus Labill dengan menggunakan metode RSM. RSM dapat digunakan untuk mempelajari hubungan antara respons dengan beberapa faktor yang berpengaruh. Kelebihan RSM yaitu dapat digunakan untuk analisis dan pemodelan dari suatu permasalahan dengan satu atau lebih perlakuan dalam penelitian (Montgomery, 2001; Bas dan Boyaci, 2007; Raissi dan Farsani, 2009). Menurut Radojkovic dkk. (2012), RSM adalah kumpulan statistik dan matematika teknik yang berguna untuk mengembangkan, meningkatkan, dan mengoptimalkan proses, yang mana respon dipengaruhi oleh beberapa faktor (variabel independen) dan mendapatkan model hubungan antara variabel bebas dan respon serta mendapatkan kondisi proses yang menghasilkan respon terbaik. Penelitian ini bertujuan untuk mendapatkan model optimasi dari konsentrasi asam formiat, konsentrasi $\mathrm{HCl}$ dan lama pemasakan untuk produksi pulp TKKS 


\section{BAHAN DAN METODE \\ Bahan dan Alat}

Bahan baku yang digunakan dalam penelitian adalah tandan kosong kelapa sawit (TKKS) dari PTPN (Persero) VII Unit Usaha Bekri Lampung Tengah. Bahan kimia yang digunakan asam asetat glacial (Merck), asam formiat (Bratachem), $\mathrm{HCl}$ (Merck), $\mathrm{H}_{2} \mathrm{SO}_{4}$ (Merck) dan aquades. Alat yang digunakan adalah pemasak pulp menggunakan Erlenmeyer Pyrex $5000 \mathrm{ml}$, hotplate (Polyscience), pendingin balik, timbangan digital 4 digit (Ohaus), tanur, oven, ruang asam dan alat-alat gelas analisis uji kimia. Peralatan disajikan pada Gambar 1.

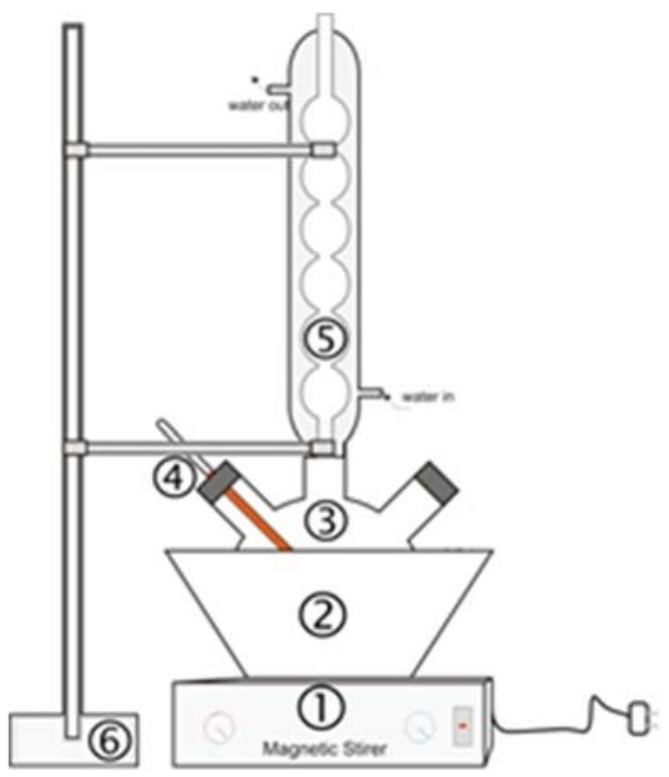

Gambar 1. Proses produksi pulp TKKS: 1) hot plate/pemanas, 2) panci pemasak, 3) labu leher tiga, 4) termometer, 5) kondensor/pendingin balik, 6) statif

Penelitian dilakukan untuk menentukan nilai optimum pada proses pulp dari TKKS dengan mengoptimasi konsentrasi asam formiat, konsentrasi $\mathrm{HCl}$, dan lama pemasakan. Metode yang digunakan yaitu metode permukaan respon (Response Surface Methode) (Box dan Diaper, 1987). Pada percobaan pembuatan model kuadratik dengan 3 variabel bebas dilakukan dengan rancangan komposit terpusat (Central Composite Design) menggunakan $\alpha=1,68, \alpha$ merupakan $2 \mathrm{k} / 4$ dmana $\mathrm{k}$ merupakan banyaknya variabel yang dicobakan. Percobaan disusun dalam bentuk $2^{3}$ faktorial dengan tiga variabel bebas yang dicobakan yaitu (1) konsentrasi formiat $\left(\mathrm{X}_{1}\right)$ terdiri dari: 3,$2 ; 10 ; 20 ; 30$ dan 36,8\% (v/v), (2) konsentrasi HCL $\left(\mathrm{X}_{2}\right)$ terdiri dari: 0,$08 ; 0,25 ; 0,5 ; 0,75$ dan $0,92 \%$ $(\mathrm{v} / \mathrm{v})(3)$ lama pemasakan $\left(\mathrm{X}_{3}\right)$ terdiri dari: 0,$32 ; 1 ; 2 ; 3$ dan 3,68 jam. Rancangan disajikan pada Tabel 1 dan 2 . Model persamaan kondisi optimum dengan desain faktorial 23 untuk kadar selulosa adalah:

$$
\begin{aligned}
Y= & \beta_{0}+\beta_{1} X_{1}+\beta_{2} X_{2}+\beta_{3} X_{3}+\beta_{12} X_{1} X_{2}+\beta_{13} X_{1} X_{3}+ \\
& \beta_{23} X_{2} X_{3}+\beta_{11} X^{2}{ }_{1}+\beta_{22} X^{2}{ }_{2}+\beta_{33} X^{2}{ }_{3}
\end{aligned}
$$

Pengolahan data menggunakan perangkat lunak Minitab versi 15 untuk mendapatkan bentuk permukaan respon dan plot kontur serta analisis keragaman dari respon penelitian.

Berat bahan baku yang digunakan dalam setiap kali pemasakan dalam penelitian ini yaitu 100 gram TKKS dan larutan pemasak $1500 \mathrm{ml}$ sesuai konsentrasi perlakuan. Perlakuan yaitu konsentrasi asam formiat, konsentrasi katalisator $\mathrm{HCl}$ dan lama pemasakan. Sebanyak 100 gram bahan baku dimasukkan ke dalam erlenmeyer $5000 \mathrm{ml}$, direndam dengan asam asetat, asam formiat $(3,2 ; 10 ; 20 ; 30$ dan $36,8 \%(\mathrm{v} / \mathrm{v}))$ dan katalis $\mathrm{HCl}(0,08 ; 0,25 ; 0,5 ; 0,75$ dan $0,92 \% \mathrm{v} / \mathrm{v}))$ selama 1 jam dengan perbandingan 1:15, kemudian direndam dan dimasak dengan suhu pemasakan $130^{\circ} \mathrm{C}$ dengan tekanan yang terjadi pada suhu tersebut dan lama pemasakan $(0,32 ; 1 ; 2 ; 3$ dan 3,68 jam). Setelah itu dilakukan penyaringan dan pencucian dengan air mengalir yang bersuhu ruang sampai netral atau hingga jernihnya air hasil pencucian. Pulp basah hasil pencucian kemudian dikeringkan pada suhu kamar sehingga diperoleh pulp kering.

\section{Pengamatan}

Pulp formacell yang diperoleh diuji rendemen dan sifat kimianya. Sifat kimia yang diuji untuk masing-masing pulp yaitu rendemen, selulosa, hemiselulosa, dan lignin metode Chesson (Datta, 1981).

\section{Rendemen}

Pulp hasil pemasakan ditimbang dalam keadaan basah (A gram), kemudian diambil contoh pulp sebanyak B gram dan dikeringkan dalam oven pada suhu $102^{\circ} \mathrm{C}$ sampai dicapai bobot konstan (C gram). Rendemen dihitung dengan rumus:

$$
\text { Rendemen }(\%)=\frac{\mathrm{C} / \mathrm{B} \times \mathrm{A}}{\text { bobot TKKS kering }} \times 100 \%
$$

Tabel 1. Faktor, kode, dan taraf kode pada proses pembuatan pulp dari TKKS

\begin{tabular}{llcccccc}
\hline \multirow{2}{*}{ No. } & \multirow{2}{*}{ Faktor } & \multirow{2}{*}{ Kode } & \multicolumn{5}{c}{ Taraf kode } \\
\cline { 4 - 7 } & & $-\alpha$ & Rendah & Tengah & Tinggi & $\alpha$ \\
\hline & & & $-1,68$ & -1 & 0 & 1 & $+1,68$ \\
1 & Asam formiat (\%) & $\mathrm{X}_{1}$ & 3,2 & 10 & 20 & 30 & 36,8 \\
2 & HCl (\%) & $\mathrm{X}_{2}$ & 0,08 & 0,25 & 0,5 & 0,75 & 0,92 \\
3 & Lama pemasakan (jam) & $\mathrm{X}_{3}$ & 0,32 & 1 & 2 & 3 & 3,68 \\
\hline
\end{tabular}


Tabel 2. Rancangan percobaan proses produksi pulp TKKS

\begin{tabular}{ccccc}
\hline Run & Asam formiat & HCl & Lama pemasakan & Parameter uji \\
\hline 1 & -1 & -1 & -1 & \\
2 & 1 & -1 & -1 & \\
3 & -1 & 1 & -1 & \\
4 & 1 & 1 & -1 & \\
5 & -1 & -1 & 1 & \\
6 & 1 & -1 & 1 \\
7 & -1 & 1 & 1 \\
8 & 1 & 1 & 0 \\
9 & 0 & 0 & 0 \\
10 & 0 & 0 & 0 \\
11 & 0 & 0 & 0 \\
12 & 0 & 0 & 0 \\
13 & 0 & 0 & 0 \\
14 & 0 & 0 & 0 \\
15 & $-1,68$ & 0 & 0 \\
16 & 1,68 & 0 & 0 \\
17 & 0 & $-1,68$ & 0 \\
18 & 0 & 1,68 & $-1,68$ \\
19 & 0 & 0 & 1,68 & \\
20 & 0 & 0 & & \\
\hline
\end{tabular}

\section{Analisis Selulosa, Hemiselulosa, dan Lignin}

Pengujian analisis selulosa, hemiselulosa dan lignin menggunakan metode Chesson (Datta, 1981). Sampel sebanyak 1 gram dimasukkan dalam gelas beker dan ditambah aquades $150 \mathrm{ml}$. Sampel selanjutnya dipanaskan selama 2 jam di dalam penangas suhu $100^{\circ} \mathrm{C}$ dan di saring dan dicuci dengan aquades sampai volume filtrat $300 \mathrm{ml}$ dan diperoleh residu. Residu dikeringkan pada oven bersuhu $105^{\circ} \mathrm{C}$ hingga beratnya konstan (a). Residu kering (a) dimasukkan dalam erlenmeyer $250 \mathrm{ml}$ ditambah $150 \mathrm{ml}$ $\mathrm{H}_{2} \mathrm{SO}_{4} 1 \mathrm{~N}$, dipanaskan pada penangas air $100^{\circ} \mathrm{C}$ selama 1 jam, setelah itu disaring dan residu dicuci dengan aquades sampai volume filtrat $300 \mathrm{ml}$. Residu dikeringkan hingga beratnya konstan dan ditimbang (b), selanjutnya residu kering (b) dimasukkan lagi ke dalam erlenmeyer $250 \mathrm{ml}$ dan ditambahkan $10 \mathrm{ml}$ $\mathrm{H}_{2} \mathrm{SO}_{4} 72 \%$ dan direndam selama 4 jam pada suhu kamar kemudian ditambahkan $150 \mathrm{ml} \mathrm{H}_{2} \mathrm{SO}_{4} 1 \mathrm{~N}$ (untuk pengenceran), dipanaskan pada penangas air suhu $100^{\circ} \mathrm{C}$ selama 2 jam, kemudian dilakukan penyaringan dan dicuci dengan aquades hingga volume filtrat $400 \mathrm{ml}$. Residu dikeringkan hingga beratnya konstan dan ditimbang (c). Residu (c) tersebut kemudian diabukan selama 6 jam $\left(600^{\circ} \mathrm{C}\right)$. Kadar lignoselulosa dapat dihitung dengan rumus :

$$
\begin{gathered}
\text { Kadar hemiselulosa }=\frac{a-b}{\text { berat sampel }} \times 100 \% \\
\text { Kadar selulosa }=\frac{b-c}{\text { berat sampel }} \times 100 \% \\
\text { Kadar lignin }=\frac{c-\text { berat abu }}{\text { berat sampel }} \times 100 \%
\end{gathered}
$$

\section{HASIL DAN PEMBAHASAN}

Hasil analisis ragam menunjukan bahwa model yang cocok adalah kuadratik ( $p$-value $=0,020$ ) yaitu lebih kecil daripada level signifikasi 5\%. Uji kecukupan model (Lack of Fit) menunjukkan bahwa model telah sesuai dengan data yang berarti model yang dibuat dapat mewakili data. Hasil tersebut ditunjukkan dengan nilai Lack of Fit sebesar 0,196 yakni lebih besar dari level signifikasi 5\%. Untuk pengujian asumsi kenormalan residual dilakukan dengan uji Kolmogorov-Smirnov dimana nilai statistik Kolmogorov-Smirnov (KS hitung) adalah 0,105, sementara nilai Kolmogorov-Smirnov dari tabel (KS tabel) untuk $\alpha=0,05$ dan jumlah pengamatan 20 adalah 0,294 (Tabel Kuantil Uji Statistik KolmogorovSmirnov). Karena KS hitung $<$ KS tabel maka residual dari model yang diperoleh telah terdistribusi normal. Untuk persamaan statistika adalah :

Kadar Selulosa $(Y)=64,2554+0,6934 X_{1}+41,0702 X_{2}$ $+1,1666 X_{3}-0,0182 X_{12}-49,3826 X_{22}-0,5423 X 32$ $-0,3429 X_{1} X_{2}+0,0686 X_{1} X_{3}-1,9307 X_{2} X_{3}$.

Hasil penelitian menunjukan bahwa nilai selulosa pulp yang dihasilkan berkisar 63,18 sampai $79,58 \%$. Konsentrasi katalisator dan jumlah asam formiat berpengaruh nyata sedangkan untuk lama pemasakan tidak berpengaruh nyata terhadap kadar selulosa. Kondisi optimum diperoleh pada konsentrasi asam formiat dan $\mathrm{HCl}$ untuk kadar selulosa berkisar antara konsentrasi 15 sampai 35\% untuk asam formiat dan konsentrasi 0,1 sampai $0,5 \%$ untuk $\mathrm{HCl}$ dan lama pemasakan 2 jam menghasilkan selulosa berkisar $75 \%$. Hasil penelitian Zhuang dkk. (2009) menunjukkan bahwa penggunaan asam formiat, asam asetat, dan air (30:50:20) dengan lama pemasakan 90 menit menghasilkan selulosa $56,87 \%$ dengan bahan baku kayu poplar. Goncalves dkk. (2005) melaporkan bahwa rasio pelarut: TKKS 1:14 (w/v) dengan suhu pulping $110^{\circ} \mathrm{C}$, dan lama pemasakan selama 2 jam dengan katalisator $\mathrm{HCl}$ memberi hasil yang baik pada pulp. Hasil penelitian Zuidar dkk. (2014) menunjukkan nilai rata-rata selulosa pulp yang dihasilkan berkisar 58,25-68,12\% untuk konsentrasi katalisator $\mathrm{HCl} 0,125$, 0,25 dan $0,5 \%$ dan lama waktu pemasakan 2 sampai 4 
jam dimana konsentrasi $\mathrm{HCl}$ berpengaruh sangat nyata terhadap kadar selulosa dari ampas tebu dan bambu betung yang dihasilkan. Lama waktu pemasakan dan interaksi antara keduanya tidak berpengaruh nyata terhadap kadar selulosa yang dihasilkan. Gambar 2 menunjukkan bahwa peningkatan asam formiat lebih besar dari 35\% dan konsentrasi $\mathrm{HCl}$ lebih besar dari $0,5 \%$ dengan lama pemasakan lebih dari 2 jam dapat menurunkan kadar selulosa sebesar $20 \%$.

Hal tersebut diduga karena adanya hidrolisis polisakarida secara kimia pada saat proses pemasakannya. Sahin dan Young (2008) menyatakan bahwa lama waktu masak yang semakin panjang akan menyebabkan reaksi depolimerisasi dari karbohidrat sehingga menyebabkan penurunan kadar selulosa yang berimplikasi akan mengurangi kekuatan sobek kertas dari 10-50\%. Fengel dan Wegener (1995) juga menyatakan bahwa hidrolisis secara kimia dalam pembuatan pulp dengan suasana asam merupakan reaksi degradasi yang paling khas terhadap glikosidaglikosida yang terikat secara glikosidik di-, oligo dan polisakarida. Dengan demikian rantai-rantai panjang selulosa akan menjadi pendek dan senyawa-senyawa hasil degradasi seperti asam-asam hidroksi akan larut saat pencucian sehingga kadar selulosa akan menjadi lebih rendah. Hal ini pun diperkuat dengan pernyataan Wanrosli dkk. (2007) yang menyatakan bahwa tingginya konsentrasi asam formiat tidak hanya melarutkan lignin ke dalam pelarut organik, tetapi selulosa juga turut terdegradasi.

Hasil penelitian menunjukan bahwa nilai ratarata hemiselulosa yang dihasilkan pada penelitian ini berkisar antara 2,6 sampai 8,9\%. Konsentrasi katalisator $\mathrm{HCl}$ dan jumlah asam formiat berpengaruh nyata sedangkan untuk lama pemasakan tidak berpengaruh nyata terhadap kadar hemiselulosa. Kondisi optimum diperoleh pada konsentrasi $\mathrm{HCl}<0,1$ sampai $0,2 \%$, asam formiat $20 \%$ dengan lama pemasakan berkisar 0,5 jam sampai 2 jam (Gambar 3). Hasil penelitian Zuidar dkk. (2014) menyatakan bahwa pembuatan pulp berbahan baku ampas tebu dan bambu betung menggunakan pelarut asam asetat dengan katalisator $\mathrm{HCl}$ pada suhu $150^{\circ} \mathrm{C}$ selama 2 dan 4 jam menghasilkan kadar hemiselulosa berkisar antara 6,94$12,34 \%$, dimana kadar hemiselulosa semakin menurun seiring dengan peningkatan konsentrasi larutan $\mathrm{HCl}$.
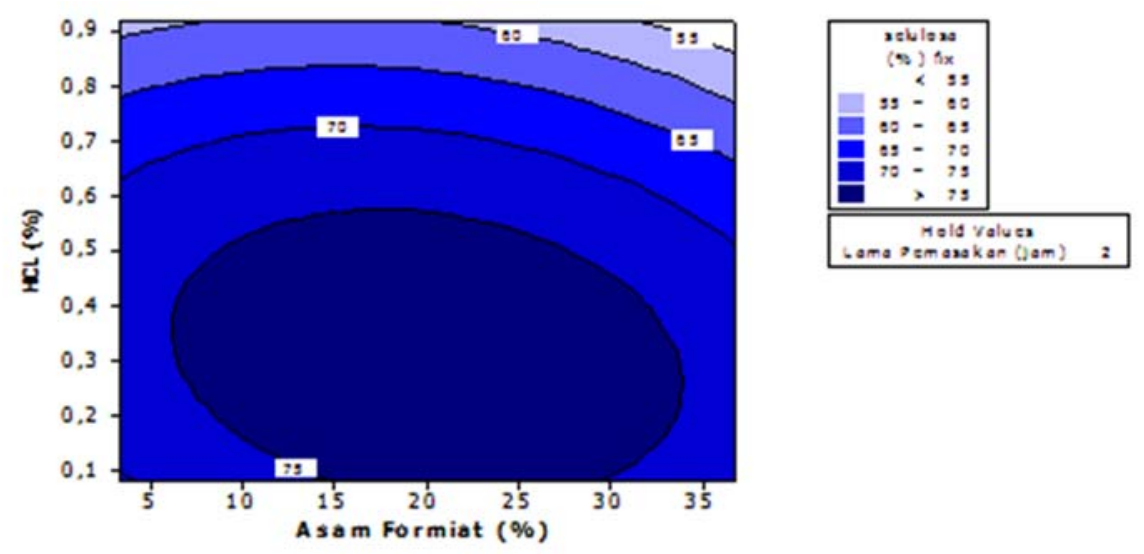

Gambar 2. Kontur respon selulosa sebagai fungsi dari $\mathrm{HCl}$ dan asam formiat pada proses pulp TKKS
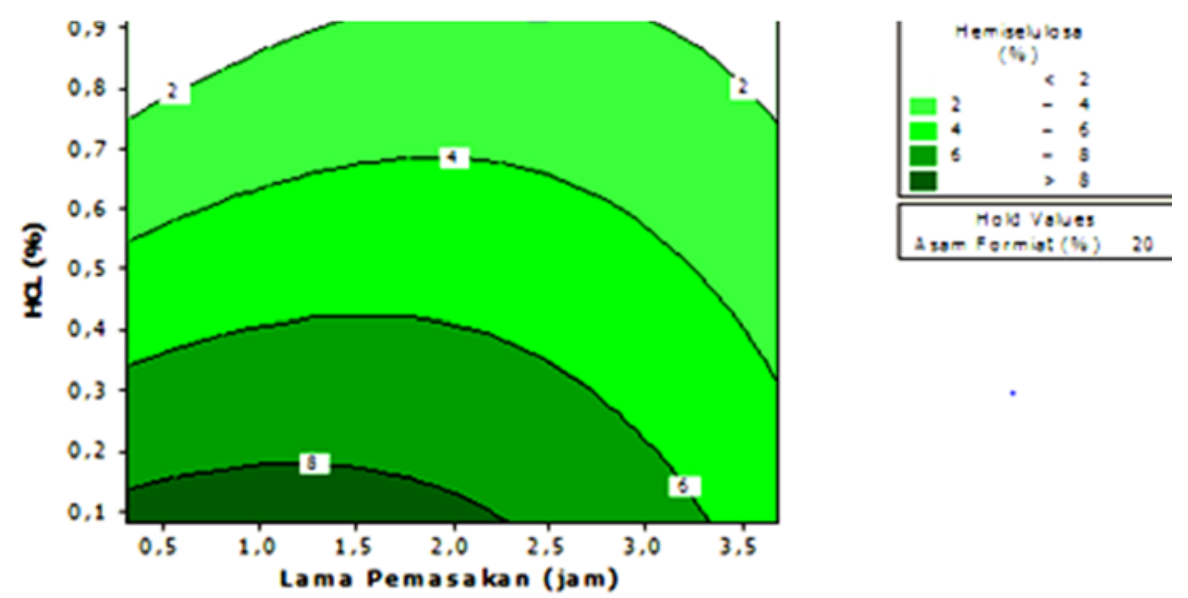

Gambar 3. Kontur respon hemiselulosa sebagai fungsi dari $\mathrm{HCl}$ dan lama pemasakan pada proses pulp TKKS 

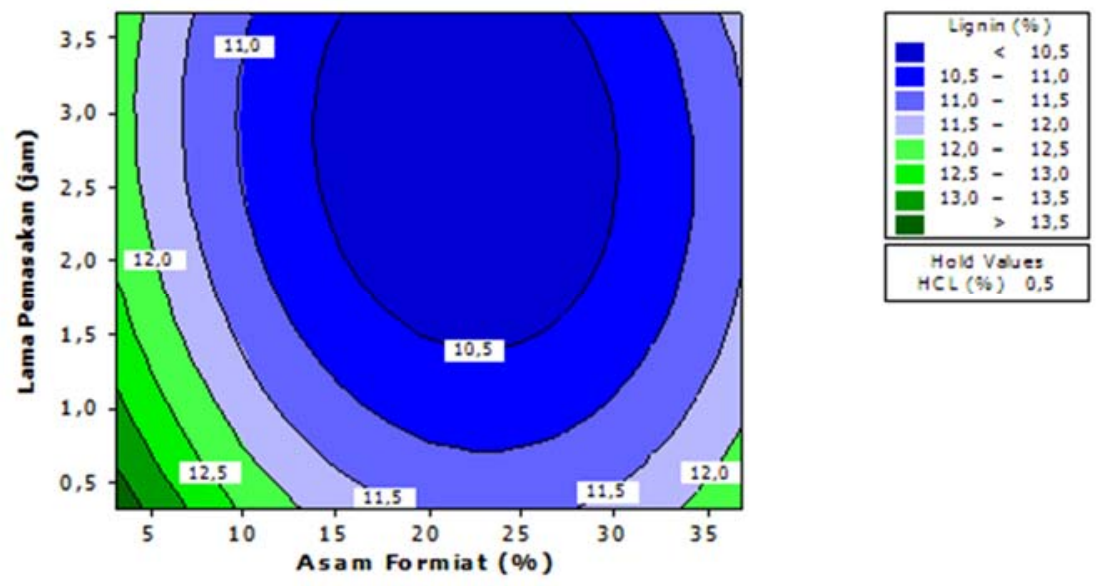

Gambar 4. Kontur respon lignin sebagai fungsi dari asam formiat dan lama pemasakan pada proses pulp TKKS.

Berdasarkan penelitian yang dilakukan Jahan dkk. (2006) diketahui bahwa penggunan asam formiat dan lama pemasakan 2 jam diperoleh hasil hemiselulosa berkisar 7,8\%. Konsentrasi asam formiat yang tinggi dapat menyebabkan penurunan kadar hemiselulosa (Wanrosli dkk., 2007) karena degradasi yang dialami oleh hemiselulosa. Peningkatan konsentrasi katalisator $\mathrm{HCl}$ lebih besar dari 0,2\%, dengan lama pemasakan lebih besar dari 2,25 jam akan menurunkan kadar hemiselulosa yang dihasilkan. Hal ini diduga karena sifat hemiselulosa mirip dengan selulosa yang mudah terdegradasi dengan larutan asam. Hemiselulosa terikat dengan polisakarida, protein dan lignin dan lebih mudah larut dibandingkan dengan selulosa (Anindyawati, 2009). Menurut Clark (1985) senyawa polisakarida seperti selulosa dan hemiselulosa terdapat ikatan glikosida yang menghubungkan rantairantai senyawa tersebut. Ikatan glikosida mudah sekali dihidrolisis oleh asam melalui reaksi kimia dan keadaan ini dipercepat dengan adanya pemanasan. Hemiselulosa akan mengalami reaksi oksidasi dan degradasi terlebih dahulu daripada selulosa, karena rantai molekul hemiselulosa lebih pendek dan bercabang. Hemiselulosa tidak larut dalam air tapi larut dalam larutan alkali encer dan lebih mudah dihidrolisa oleh asam daripada selulosa (Fengel dan Wegener, 1995).

Hasil penelitian menunjukan bahwa yield lignin yang dihasilkan pada penelitian ini berkisar antara 6,1 sampai $15,9 \%$. Konsentrasi asam formiat, $\mathrm{HCl}$ dan lama pemasakan berpengaruh nyata terhadap kadar lignin. Kadar lignin terkecil diperoleh pada konsentrasi $\mathrm{HCl}$ lebih dari $0,5 \%$, asam formiat 15 sampai $30 \%$ dengan lama pemasakan berkisar 1,5 sampai 3 jam. Penggunaan asam formiat kurang dari $15 \%$ dan lama pemasakan kurang dari 1,5 jam menyebabkan lignin masih tinggi. Hal ini diduga karena proses delignifikasi masih belum terjadi pada saat pemasakan (Gambar 4).

Zulfansyah dkk. (2011) melaporkan bahwa kadar lignin setelah pemasakan menggunakan asam formiat dan lama pemasakan 1-3 jam diperoleh kadar lignin pulp TKKS yang dihasilkan sebesar 11,20$19,12 \%$ dengan waktu pemasakan yang lebih lama menjadi faktor yang paling berpengaruh terhadap kadar lignin pulp TKKS yang dihasilkan. Zhuang dkk. (2009) menyatakan bahwa asam formiat dan asam asetat dapat mendelignifikasi lignin dikarenakan sifatnya yang asam sehingga dapat mendegradasi lignin dengan baik. Asam formiat:asam asetat: air (30:50:20), rasio pelarut dengan bahan $1: 12$ dan dengan suhu $105^{\circ} \mathrm{C}$ selama 90 menit menghasilkan lignin sebesar 18,17\%.

Penurunan lignin pada proses pemasakan pulp TKKS diduga karena adanya proses delignifikasi pada saat pemasakan. Delignifikasi adalah proses pemecahan lignin menjadi lebih sederhana dengan bantuan asam, suhu dan lama pemasakan. pembuatan pulp acetosolv mampu fraksionasi yang bahan lignoselulosa menjadi selulosa (serat pulp), lignin asam dan monosakarida. Itu dikonfirmasi bahwa proses delignifikasi asam ini disebabkan oleh hidrolisis ikatan eter $\alpha$-aril (Gierer, 1980; Ljunggren, 1980). Sebuah model kinetik yang disarankan terdiri dari dua proses berturut-turut yaitu lignin pelarutan diikuti oleh lignin kondensasi (Davis dkk., 1986; Parajó dkk., 1995). Kadar lignin pulp pelepah sawit yang dihasilkan dengan pemasakan menggunakan larutan asam formiat cenderung berkurang dengan bertambahnya lama pemasakan pada setiap konsentrasi asam formiat yang digunakan (Zulfansyah dkk., 2011). Akan tetapi pemasakan terlalu lama dan bertambahnya konsentrasi larutan asam diduga mengakibatkan lignin mengalami kondensasi kembali ke bahan (TKKS) sehingga mengakibatkan lignin yang dihasilkan kembali tinggi.

Hal tersebut terjadi karena pemakaian konsentrasi asam organik yang lebih pekat cenderung mendorong terjadinya reaksi polimerisasi kembali lignin yang telah larut dalam cairan pemasak, sehingga kadar lignin pulp kembali meningkat (Parajo dkk., 1993; Muurinen, 2000). Zuidar (2007) menyatakan bahwa kadar lignin yang tinggi hasil pemasakan pulp diduga akibat terjadinya proses kondensasi sehingga lignin mengendap pada permukaan pulp sehingga warna menjadi lebih gelap. Proses kondensasi terbentuk dengan penggabungan rantai-rantai karbon yang membentuk rantai lebih panjang, dimana senyawa yang terbentuk merupakan zat antara ion karbonium 
misalnya dapat dilihat dari perubahan warna yang terbentuk pada pulp (Fengel dan Wegener, 1995).

Morfologi TKKS sebelum dan perlakuan formacell diuji dengan menggunakan Scanning Electron Microscope (SEM) dengan perbesaran 500x (Gambar 5). Hasil penelitian menunjukkan bahwa proses pulping TKKS dengan menggunakan metode formacell menghasilkan perubahan morfologi permukaan TKKS. Permukaan TKKS setelah mengalami proses pulping secara formacell terlihat lebih lebar dibandingkan TKKS sebelum mengalami pulping dan bulatan yang ada di dalam serat TKKS yang diduga lignin sudah mulai hilang pada proses pulping secara formacell dan sifat kristalinitas dari TKKS mulai berkurang ditandai dengan bentuk TKKS yang semula rigid menjadi agak mengacak. Kondisi serat yang panjang dan susunan serat yang kompak memungkinkan pulp formacell akan menghasilkan pulp dan kertas dengan kekuatan yang relatif baik.

Hasil penelitian menunjukan bahwa nilai ratarata rendemen yang dihasilkan pada penelitian ini berkisar antara 41,4 sampai $86,4 \%$ dengan rata-rata sebesar 68,5\%. Lama pemasakan dan konsentrasi asam formiat berpengaruh nyata sedangkan konsentrasi katalisator $\mathrm{HCl}$ tidak berpengaruh nyata terhadap rendemen pulp yang dihasilkan. Kondisi optimum

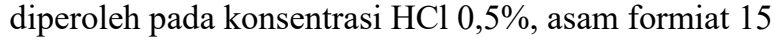
sampai $20 \%$ dengan lama pemasakan berkisar 1,5 jam sampai 2 jam. Fatriasari dkk. (2010) menyatakan bahwa nilai rata-rata keseluruhan rendemen pulp TKKS adalah 62,74\%. Rendemen berkurang tajam dengan bertambahnya pekatnya asam formiat dalam larutan pemasak. Zuidar dkk. (2014) melaporkan bahwa lama pemasakan berpengaruh sangat nyata terhadap rendemen pulp yang dihasilkan dengan waktu pemasakan 2 jam. Nilai rata-rata rendemen pulp yang dihasilkan berkisar antara 53,26-58,56\%.

Penggunaan asam formiat lebih dari $30 \%$ dan lama pemasakan lebih dari 2,5 jam menyebabkan rendemen berkurang (Gambar 6 dan 7). Hal ini diduga karena pemasakan dengan larutan asam memiliki sifat reaktif, sehingga dapat memutuskan ikatan kompleks lignin-polisakarida yang mengakibatkan semakin rendahnya rendemen pulp yang dihasilkan. Menurut Fatriasari dan Risanto (2011) menyatakan bahwa peningkatan konsentrasi bahan kima cenderung menurunkan rendemen total pulp. Hal tersebut terjadi karena dengan konsentrasi yang semakin tinggi maka jumlah selulosa yang terdegradasi semakin tinggi.

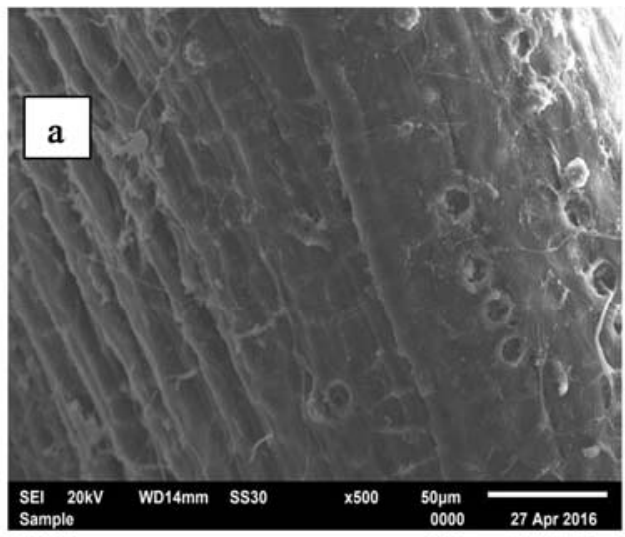

(a) TKKS sebelum pulping

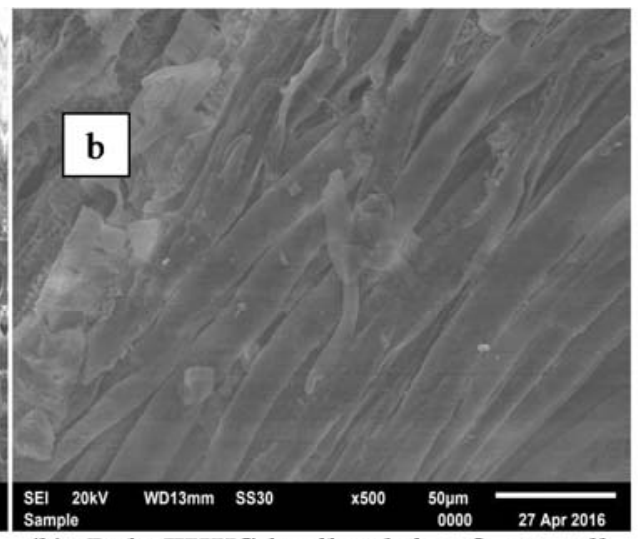

(b) Pulp TKKS hasil pulping formacell

Gambar 5. Hasil analisis SEM TKKS sebelum dan sesudah di pulping (perbesaran 500x)
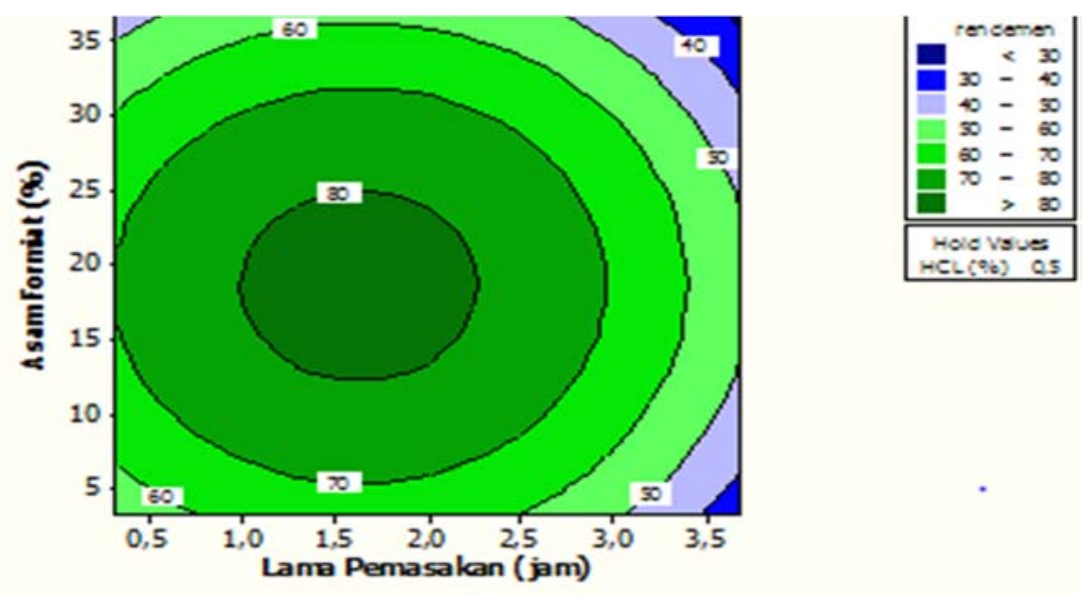

-

Gambar 6. Kontur respon rendemen sebagai fungsi dari $\mathrm{HCl}$ dan asam formiat pada proses pulp TKKS 


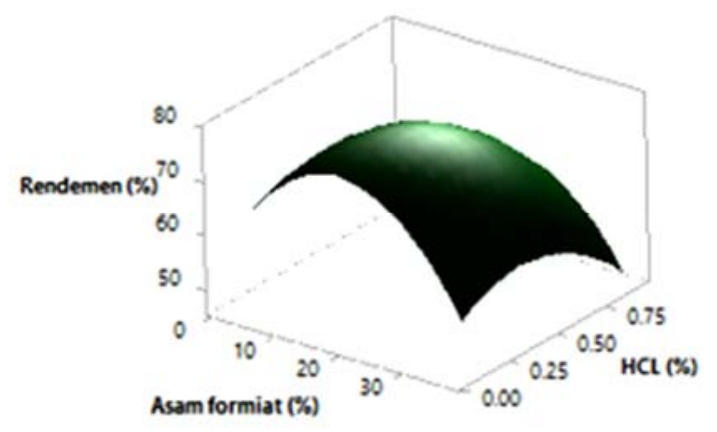

Hold Values

Lama pemasakan (jam) 2

Gambar 7. Permukaan respon rendemen sebagai fungsi dari $\mathrm{HCl}$ dan asam formiat pada proses pulp TKKS

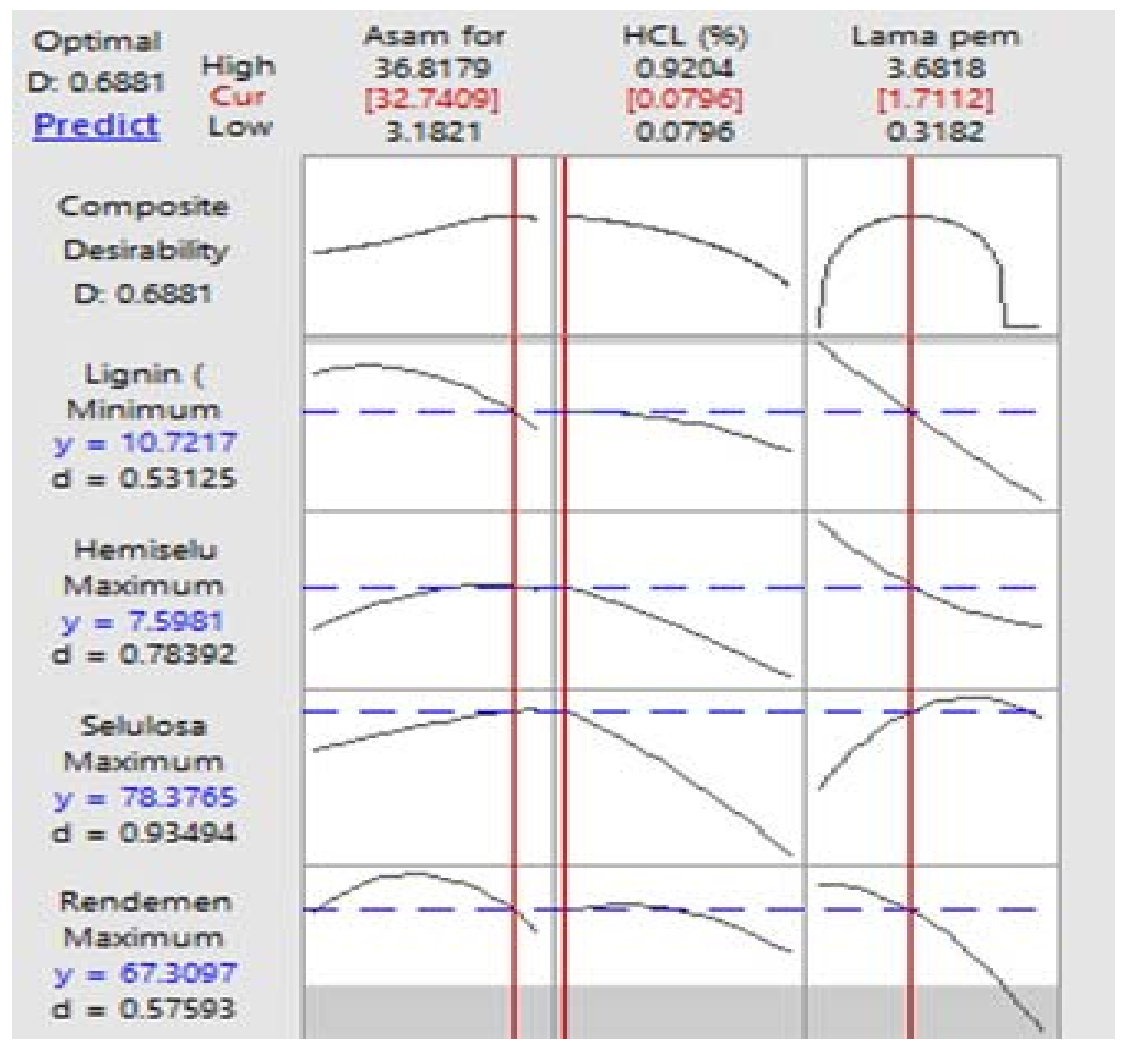

Gambar 8. Optimisasi RSM pembuatan pulp formacell dari tandan kosong sawit

Dalam pembuatan pulp diinginkan produk pulp dengan selulosa dan rendemen serta kadar lignin yang rendah. Kondisi optimasi proses yang terbaik yang menghasilkan pulp optimum dilihat pada Gambar 8 .

Nilai optimum untuk menghasilkan selulosa tertinggi yaitu $78,37 \%$, rendemen $67,31 \%$, hemiselulosa $7,59 \%$ dan lignin $10,72 \%$, dicapai paada kondisi operasi konsentrasi asam formiat sebesar $32,74 \%$, konsentrasi $\mathrm{HCl}$ sebesar 0,079\%, dan lama pemasakan 1,71 jam.

\section{KESIMPULAN}

Hasil penelitian menghasilkan nilai $\mathrm{R}^{2} 83 \%$, lack of fit 0,196 dan nilai optimum untuk menghasilkan selulosa tertinggi terjadi pada konsentrasi asam formiat sebesar 32,74\%, konsentrasi $\mathrm{HCl}$ sebesar $0,079 \%$, dan lama pemasakan 1,71 jam dengan nilai pada hasil optimum pulp TKKS untuk setiap parameter ujinya berturut-turut adalah 78,37\% selulosa, 7,59\% hemiselulosa, 10,72\% lignin, dan 67,31\% rendemen. 


\section{DAFTAR NOTASI}

\begin{tabular}{|c|c|}
\hline Y & $=$ respons selulosa \\
\hline$\beta_{0}$ & $=$ intersep \\
\hline$\beta_{1}, \beta_{2}, \beta_{3}, \beta_{4}$ & $\begin{array}{l}=\text { koefisien regresi variabel } \mathrm{X}_{1}, \mathrm{X}_{2}, \\
\mathrm{X}_{3}\end{array}$ \\
\hline$\beta_{12}, \beta_{13}, \beta_{23}$ & $=$ koefisien interaksi antar faktor \\
\hline$\beta_{11}, \beta_{22}, \beta_{33}$ & $=$ koefisien kuadratik $\mathrm{X}_{1}{ }_{1}, \mathrm{X}^{2}{ }_{2}, \mathrm{X}^{2}{ }_{3}$ \\
\hline A & $=$ bobot total pulp basah $(\mathrm{g})$ \\
\hline B & $=$ bobot contoh pulp basah $(\mathrm{g})$ \\
\hline $\mathrm{C}$ & $=$ bobot contoh pulp kering $(\mathrm{g})$ \\
\hline $\mathrm{a}$ & $=$ berat residu awal kering $(\mathrm{g})$ \\
\hline $\mathrm{b}$ & $\begin{aligned}= & \text { berat residu kering setelah } \\
& \text { penambahan } \mathrm{H}_{2} \mathrm{SO}_{4} 1 \mathrm{~N}(\mathrm{~g})\end{aligned}$ \\
\hline $\mathrm{c}$ & $\begin{aligned} &= \text { berat residu kering setelah } \\
& \text { penambahan } \mathrm{H}_{2} \mathrm{SO}_{4} \quad 72 \% \text { dan } \\
& \\
& \mathrm{H}_{2} \mathrm{SO}_{4} 1 \mathrm{~N}(\mathrm{~g})\end{aligned}$ \\
\hline
\end{tabular}

\section{DAFTAR PUSTAKA}

Anindyawati, T., (2009), Prospek Enzim dan Limbah Lignoselulosa untuk Produk Bioetanol, Jurnal LIPI, 44(1), hal. 49-56.

Aremu, M.O., Aperolola, S.O., and Dabonyan, O.O., (2015), Suitability of Nigerian Corn Husk and Plantain Stalk for Pulp and Paper Production, European Scientific Journal, 11(30), pp. 146-152.

Aziz, S. and Sarkanen, K., (1989), Organosolv Pulping, A Review, Tappi Journal, 72(3), pp. 169-175.

Bas, D. and Boyaci, I.H., (2007), Modelling and Optimization I: Usability of Response Surface Methodology, Journal of Food Engineering, 78 (3), pp. 836-845.

Box, G.E.P. and Diaper, N.R., (1987), Empirical Model Building and Respon Surfaces, John Willy and Son, New York, pp. 1-688.

Clark, J.A., (1985), Pulp Technology and Treatment For Paper, 2nd Ed., Miller Freeman Publications Inc., San Francisco, California, pp. 1-751.

Darnoko, Guritno, P., Sugiharto, A., dan Sugesty, S., (1995), Pembuatan Pulp dari Tandan Kosong Sawit dengan Penambahan Surfaktan, Jurnal Penelitian Kelapa Sawit, 3(1), hal. 75-87.

Datta, R., (1981), Acidogenic Fermentation of Linocellulose Acid Yield Convertion of Components, Biotechnology and Bioengineering, 23(9), pp. 21672170.

Davis, J.L., Young, R.A., and Deodhar, S.S, (1986), Organic Acid Pulping of Wood. III. Acetic Acid Pulping of Spruce, Mokuzai Gakkaishi, 32(11), pp. 905-914.

de la Torre, M.J., Moral, A., Hernández, M.D., Cabeza, E., and Tijero, A., (2013), Organosolv Lignin for
Biofuel, Industrial Crops and Products Journal, 45, pp. 58-63.

Dominggus, Y. and Laszio, P., (2004), Anionic Effect in High Concentration Alcohol Organosolv Pulping, Holzforschung, 58(1), pp. 1-6.

Fengel, D. dan Wegener, G., (1995), Kayu : Kimia, Ultrastruktur, Reaksi-reaksi, Diterjemahkan oleh Hardjonosastro Hamidjojo, Universitas Gajah Mada Press, Yogyakarta, hal. 1-729.

Fatriasari, W., Sita, H.A., Faizul, F., Triyono, N.A., dan Euis, N.A., (2010), Biopulping Bambu Betung Menggunakan Kultur Campur Jamur Pelapuk Putih (Trametes Versicolor, Pleurotus Ostreatus dan Phanerochaete Crysosporium), UPT BPP Biomaterial LIPI Bogor, 45(2), hal. 44-56.

Fatriasari, W. dan Risanto, L, (2011), Sifat Pulp Kraft Kayu Sengon (Paraserianthes Falcataria): Perbedaan Konsentrasi Bahan Pemasak dan Tahap Pemutihan, Widyariset, 14(3), hal. 589-597.

Fang, W. and Sixta, H., (2015), Advanced Biorefinery Based on The Fractionation of Biomass in Valerolactone and Water, Chem. Sus. Chem. Journal, 8, pp. 73-76.

Gierer, J., (1980), Chemical Aspects of Kraft Pulping, Wood Science Technology, 14, pp. 241-266.

Goncalves, A.R., Denise, D., Moriya, R., and Oliveria, L.R.M., (2005), Pulping of Sugarcane Bagasse and Straw and Biobleaching of the Pulps: Conditions Parameters and Recycling of Enzymes, Appita Conference, Auckland, 16-19 May.

Hergert, H.L., (1998), Developments in Organosolv Pulping: An Overview. In: Environmental Friendly Technologies for the Pulp and Paper Industry, Eds. Young, R.A., Akhtar, M., Wiley, New York. pp. 5-67.

Ibrahim, M., Sarwar, M.J., and Ali, H., (2004), Effect of Inorganic Acid Catalyst on the Acetosolv Pulping of Maize Stalk, Journal Cellulose Chemistry and Technology, 38 (2), pp. 87-94.

Jahan, M., Sarwar, Lee, Z.Z., and Jin, Y., (2006), Organic Acid Pulping of Rice Straw, Part-I: Cooking, Turkish Journal of Agricultural Forestry, 30(3), pp. 231-239.

Jimenez, L.V., Angulo, E., Ramos, M.J., De la Torre, J.L., and Ferrer, (2006), Comparison of Various Pulping Processes for Producing Pulp from Vine Shoots, Industrial Crops and Products, 23, pp. 122130 .

Lam, H., Bigot, Y.L., Imas, M., and Avignon, G., (2001), Formic Acid Pulping of Rice Straw, Industrial Crops and Products, 14, pp. 65-71. 
Lavarack, B.P., Rainey, T.J., Falzon, K.L., and Bullock, G.E., (2005), A Preliminary Assessment of Aqueous Ethanol Pulping of Bagasse: The Ecopulp Process, International Sugar Journal, 107, pp. 611615.

Law, K.N., Daud W.R.W., and Ghazali, A., (2007), Morphological and Chemical Nature of Fiber Strands of Oil Palm Empty-Fruit-Bunch (OPEFB), Bioresource Technology, 2(3), pp. 351-362.

Li, M.F., Sun, S.N., Xu, F., and Sun, R.C., (2012), Organosolv Fractionation of Lignocelluloses for Fuels, Chemicals and Materials: A Biorefinery Processing Perspective. In: Biomass Conversion, The Interface of Biotechnology, Chemistry and Materials Science, Editors, Springer Berlin, Heidelberg, pp. 341-379.

Ljunggren, S., (1980), The Significance of Aryl Ether Cleavage in Kraft Delignification of Softwood, Sven Papperstidn, 83(13), pp. 363-369.

Ligero, P., Villaverde, J.J., Vega, A., Bao, M., (2007), Acetosolv Delignification of Depithed Cardoon (Cynara cardunculus) Stalks, Industrial Crops and Products, 27, pp. 294-300.

Ligero, P., Vega, A., Bao, M., (2005), Acetosolv Delignification of Miscanthus Sinensis Bark Influence of Process Variables, Industrial Crops and Products, 21, pp. 235-240.

Linder, M., Kochanowsk, Ni, and Parmentier, (2005), Response Surface Optimisation of Lipase-Catalysed Esterification of Glycerol and n-3 Polyunsaturated Fatty Acids from Salmon Oil, Process Biochemistry, 40, pp. 273-279.

López, F., Alfaro, A., Jiménez, L., and Rodríguez, A., (2006), Alcohols as Organic Solvents for The Obtainment of Cellulose Pulp, Afinidad, 63(523), pp. 174-182.

Madakadze, I.C., Radiotis, T., Li, J., Goel, K., and Smith, D.L., (1999), Kraft Pulping Characteristics and Pulping Properties of Warm Season Grasses, Bioresource Technology, 69, pp. 75-78.

Montgomery, D.C., (2001), Design and Analysis of Experimental, John Wiley \& Sons Inc, New York, pp. $1-500$.

Muurinen, E., (2000), Organosolv Pulping (A Review and Distillation Study Related to Peroxyacid Pulping), Fakultas Teknologi Universitas Oulu, Linnanmaa, pp. 1-314.

Neiva, D.M, Gominho, J., and Pereira, H., (2014). Modeling and Optimization of Eucalyptus globulus Bark and Wood Delignification using Response Surface Methodology, Bio Resources, 9(2), pp. $2907-$ 2921.
Nimz, H.H. and Schoen, M., (1993), Non Waste Pulping and Bleaching with Acetic Acid, ISWPC Proceeding, Beijing, pp. 258-265.

Nogales, J.M.R., Roura, E., and Contreas, E., (2005), Biosynthesis of Ethyl Butyrate Using Immobilized Lipase: A Statistic Approach, Process Biochemistry, 40, pp. 63-68.

Pan, X. and Sano, Y., (2005), Fractionation of Wheat Straw by Atmospheric Acetic Acid Process, Bioresource Technology, 96, pp. 1256-1263.

Pan, XJ. and Sano, Y., (1999), Acetic Acid Pulping of Wheat Straw Under Atmospheric Pressure, Journal Wood Science, 45, pp. 319-325.

Pan, X., Gilkes, N., Kadla, J., Pye, K., Saka, S., Gregg, D., and Ehara. K., (2006), Bioconversion of Hybrid Poplar to Ethanol and Co-Products using An Organosolv Fractionation Process: Optimization of Process Yields, Biotechnology and Bioengineering, 94, pp. 851-861.

Parajo, J.C., Alonso, J.L., Vazquez, D., and Santos, V., (1993), Optimization of Catalyzed Acetosolv Fractionation Of Pine, Holzforschung, 4, pp. 188-196.

Parajó, J.C., Alonso, J.L., and Santos, V., (1995), Kinetics of Catalyzed Organosolv Processing of Pine Wood, Industrial \& Engineering Chemistry Research, 34, pp. 4333-4342.

Radojkovic, M., Zekovic, Z., Jokic, S., and Vidovic, S., (2012), Determination of Optimal Extraction Parameters of Mulberry Leaves Using Response Surface Methodology (RSM), Romanian Biotechnological Letters, 17(3), pp. 7295-7308.

Raissi, S. and Farzani, R.E., (2009), Statistical Process Optimization Through Multi-Response Surface Methodology, World Academy of Science, Engineering and Technology, 51, pp. 267-271.

Rao, R.B., Manohar, K., Sambiah, and Lokesh, B.R., (2002), Enzymatic Acidolysis In Hexane To Produce N-3 Or N-6 FA-Enriched Structured Lipids from Coconut Oil: Optimization of Reactions by Response Surface Methodology, Journal of the American Oil Chemists’ Society, 70 (9), pp. 885-890.

Rodríguez, A. and Jiménez, L., (2008), Pulping with Organic Solvents Others than Alcohols, Afinidad, 65(535), pp. 188-196.

Sahin, H.T. and Young, R.A. (2008). Auto-Catalyzed Acetic Acid Pulping of Jute, Industrial Crops and Products, 28(1), pp. 24-28.

Satria, R., Sani, I.M., Holy, V., Rionaldo, H., Zulfansyah, dan Amraini, S.Z., (2010), Optimasi Pembuatan Pulp Semi Mekanis Tandan Kosong kelapa 
Sawit dengan Metode RSM-CCD, Proceeding National Conference on Chemical Engineering Science and Applications, hal. 1-8.

Shatalov, A.A. and Pereira, H., (2004), Arundo donax L. Reed: New Perspectives for Pulping And Bleaching. Part 3. Ethanol Reinforced Alkaline Pulping, Tappi Journal, 3(2), pp. 27-31.

Sidiras, D. and Koukios, E., (2004), Simulation of Acid-Catalysed Organosolv Fractionation of Wheat Straw, Bioresources Technology, 94(1), pp. 91-98.

Simkhovich, B.S., Zilbergleit, M.A., and Reznikov, V.M., (1987), Papermaking Properties of Acetic Acid Pulp from Hardwoods, Bum Prom, 7, pp. 25-26.

Susanto, H., Rusmanto, and Sudrajat, A., (1999), Production of Lignosulfonat From Lignin in Black Liquor of Ethanosolv-Pulping, Prosiding Seminar Nasional Fundamental dan Aplikasi Teknologi Kimia (2), pp. 1-6.

Tu, Q., Fu, S., Zhan, H., Chai, X., and Lucia, L.A., (2008), Kinetic Modeling Of Formic Acid Pulping of Bagasse, Journal of Agricultural and Food Chemistry, 56 (9), pp. 3097-3101.

Vila, C., Santos, V., and Parajo, J.C., (2000). Optimization of Beech Wood Pulping Incatalyzed Acetic Acid Media, The Canadian Journal of Chemical Engineering, 78, pp. 964-973..

Wanrosli, W.D., Zainuddin, Z., Law, K.N and Asro, R., (2007), Pulp from Oil Palm Fronds by Chemical Process, Industrial Crop and Producs, 25, pp. 89-94.

Yawalata, D. and Paszner, L., (2004), Anionic Effect in High Concentration Alcohol Organosolv Pulping, Holzforschung, 58(1), pp. 1-6.
Zhou, S., Liu, L., Wang, B., Xu, F., and Sun, R.C., (2012), Microwave-Enhanced Extraction of Lignin from Birch in Formic Acid: Structural Characterization and Antioxidant Activity Study, Process Biochemistry Journal, 47, pp. 1799-1806.

Zhao, X. and Liu, D., (2012), Fractionating Pretreatment of Sugarcane Bagasse by Aqueous Formic Acid with Direct Recycle of Spent Liquor to Increase Cellulose Digestibility-The Formiline Process, Bioresources Technology, 117, pp. 25-32.

Zhang, M., Qi, W., Liu, R., Su, R., Wu, S and He, Z., (2010), Fractionating Lignocellulose by Formic Acid: Characterization of Major Components, Biomass Bioenergy, 34, pp. 525-532.

Zhuang, J., Lin, L., Liu, J., Lou, X., Pang, C., and Ouyang, P. (2009) Preparation of Xylose and Kraft Pulp from Poplar Based on Formic/Acetic Acid/Water System Hydrolysis, Bioresources, 4(3), pp. 11471157.

Zuidar, A.S., (2007), Pengaruh Konsentrasi Larutan Pemasak dan Nisbahnya dengan Bobot Bagase Terhadap Rendemen dan Sifat Fisik Pulp Bagase (Acetosolve), Agritek Institut Pertanian Malang, 15 (3), hal. 652-657.

Zuidar, A.S., Hidayati, S. dan Ferdiyanto, (2014). Kajian Penggunaan Asam Klorida pada Proses Produksi Pulp Acetosolv dari Ampas Tebu dan Bambu Betung, Prosiding Seminar Nasional BKS PTN Barat, hal. 1292-1298.

Zulfansyah, Fermi, M.I., Amraini, S.Z., Rionaldi, H. dan Utami, M.S., (2011), Pengaruh Kondisi Proses terhadap Yield dan Kadar Lignin Pulp dari Pelepah Kelapa Sawit dengan Proses Asam Formiat, Jurnal Rekayasa Kimia dan Lingkungan, 9(1), hal. 12-19. 